\title{
Analisa Risiko Supply Chain Management dengan Metode Grey Failure Mode and Effect Analysis dan Root Cause Analysis di PT Pertamina Fuel Terminal Meulaboh
}

\author{
Muhammad Rizki ${ }^{1}$, Arie Saputra ${ }^{2 *}$ \\ ${ }^{1,2}$ Prodi Teknik Industri, Fakultas Teknik, Universitas Teuku Umar, Meulaboh \\ *Koresponden email : arie.saputra@utu.ac.id
}

Diterima: 9 Januari 2022

Disetujui: 25 Januari 2022

\begin{abstract}
PT. Pertamina Fuel Terminal Meulaboh is a business unit of PT. Pertamina (Persero) under the function of Supply \& Distribution has the main task of carrying out the activities of receiving, stockpiling, and distributing fuel oil. In the distribution and operation processes carried out, 8 risks may occur. Based on the Gray FMEA method, the priority risk that occurs is the delay of the tanker which has the smallest gray relationship, which is 0.435 and the risk of the interconnection of information system support between functions which is still problematic is 0.452. Through the Root Cause Analysis method approach, the root causes of the risk of ship delays are non-routine maintenance/maintenance on ship engines, lack of training for crew members according to function, and bad weather conditions. Meanwhile, the risk of the interconnection of information systems support between functions is still problematic due to the lack of maintenance and network management. The alternative strategy for improvement that can be done by the company is to work with the BMKG to help predict the weather, improve the quality of workers according to their functions, provide adequate equipment and reliable mechanics to carry out SOPs for maintaining ship engines properly and cooperate with service management companies to assist companies in managing and maintaining networks.
\end{abstract}

Keywords: risk analysis, supply chain management, grey failure mode, root cause analysis, Pertamina

\begin{abstract}
Abstrak
PT. Pertamina Fuel Terminal Meulaboh adalah unit bisnis PT. Pertamina (Persero) dibawah fungsi Supply \& Distribution yang mempunyai tugas pokok dalam melaksanakan kegiatan penerimaan, penimbunan, dan penyaluran bahan bakar minyak. Dalam proses distribusi dan operasi yang dilaksanakan terdapat 8 risiko yang memungkinkan terjadi. Berdasarkan metode Grey FMEA, risiko prioritas yang terjadi adalah keterlambatan kapal tanker yang memiliki hubungan grey terkecil yaitu 0,435 dan risiko pada dukungan interkoneksi sistem informasi antar fungsi yang masih bermasalah sebesar 0,452. Melalui pendekatan metode Root Cause Analysis akar permasalahan risiko keterlambatan kapal adalah tidak rutinnya maintance/perawatan pada mesin kapal, kurangnya pelatihan pada awak kapal sesuai fungsi, dan kondisi cuaca buruk. Sedangkan risiko pada dukungan interkoneksi sistem informasi antar fungsi yang masih bermasalah diakibatkan oleh kurang nya perawatan dan pengelolaan jaringan. Adapun strategi alternatif perbaikan yang dapat dilakukan perusahaan adalah bekerja sama dengan pihak BMKG untuk membantu memprediksikan cuaca, meningkatkan kualitas pekerja sesuai fungsinya, menyediakan peralatan yang memadai dan mekanik yang handal untuk menjalankan SOP pewatan mesin kapal dengan baik dan bekerja sama bersama perusahaan jasa manage service untuk membantu perusahaan dalam mengelola dan merawat jaringan.
\end{abstract}

Kata Kunci: analisis risiko, manajemen rantai pasok, grey failure mode, root cause analisys, pertamina

\section{Pendahuluan}

Risiko pada supply chain management perusahaan terjadi akibat adanya vulnerability (kesenjangan) di proses aliran distribusi. Risiko yang terjadi dapat berupa kerugian kecil maupun kerugian besar yang dapat menghambat operasional perusahaan [1]. Kesenjangan tersebut disebabkan oleh dua faktor yaitu faktor internal dan faktor eksternal. Faktor internal adalah faktor risiko yang dapat dikendalikan oleh perusahaan seperti tenaga kerja dan sistem informasi, sedangkan faktor eksternal adalah faktor risiko yang tidak dapat dikendalikan oleh perusahaan, misalnya kondisi cuaca dan suppliers [2]. Supply chain management adalah suatu sistem organisasi, suppliers dan proses yang saling terintegrasi untuk 
memperoleh bahan baku dan diolah menjadi produk bernilai, kemudian diteruskan kekonsumen melalui sistem distribusi [3]. Keterbatasan informasi mengenai risiko pada supply chain management mengakibatkan perusahaan perlu melakukan identfikasi. Tujuan identifikasi dilakukan agar dapat diketahui akar penyebab risiko dan menjadi usulan pengambilan keputusan perbaikan bagi yang efektif, efisien dan responsif [4].

PT. Pertamina Fuel Terminal Meulaboh merupakan unit perusahaan PT. Pertamina yang bertugas melaksanakan kegiatan penerimaan, penimbunan dan penyaluran bahan bakar minyak (BBM). Pola operasi Fuel Terminal Meulaboh yaitu melaksanakan penerimaan BBM melalui kapal tanker dengan menggunakan fasilitas CBM (Conventional Bouy Mooring) dan melakukan penyimpanan BBM di tangki timbun, lalu kemudian menyalurkan BBM melalui mobil tangki kepada customer. Namun, dalam melaksanakan tugasnya PT. Pertamina FT Meulaboh saat ini sering mengalami risiko pada Supply Chain management. Salah satu risiko supply chain management yang pernah terjadi adalah keterlambatan kapal tanker sehingga mengakibatkan kekurangan stok produk untuk disalurkan ke customer. Selain itu dukungan interkoneksi yang bermasalah juga menghambat aktifitas penggunaan sistem informasi perusahaan.

Berdasarkan permasalahan diatas, penulis bermotivasi untuk melakukan identifikasi risiko di PT Pertamina FT Meulaboh menggunakan metode Grey Failure Mode and Effect Analysis (FMEA) dan mencari akar permasalahannya dengan metode Root Cause Analysis (RCA). Grey FMEA adalah metode yang digunakan untuk mengidentifikasi masalah yang dapat mengakibatkan suatu kegagalan pada suatu sistem [5]. Pada penelitian sebelumnya oleh ref. [6], penggunaan metode Grey FMEA digunakan untuk mengidentifikasi kerusakan pompa P-0402 berdasarkan tingkat risiko [6]. Dalam penelitian ini, Grey FMEA digunakan untuk mengidentifikasi risiko pada supply chain management. Selain itu, penelitian dalam mencari akar permasalahan menggunakan Root Cause Analysis jenis 5 whys tools pernah dilakukan oleh ref. [7], akar permasalahan yang didapatkan yaitu proses jasa pengiriman barang yaitu tidak ada tanggung jawab driver dari kepala operasional, tidak ada kesepakatan antara driver dan konsumen, sistem perusahaan yang kurang baik, dan tidak adanya standarisasi admistrasi dokumen. Namun dalam penelitian tersebut akar permasalahan yang dirumuskan adalah waste, sedangkanpenulis dengan metode yang sama merumuskan akar permasalahan risiko yang terjadi diperusahaan [7].

\section{Metode Penelitian}

Penelitian ini dilakukan di PT Pertamina FT Meulaboh, data yang didapatkan adalah berdasarkan hasil pengamatan dan wawancara bersama Jr. Spv Receiving \& Storage (RS). Tahapan-tahapan dari penelitian dapat dilihat pada Gambar 1.

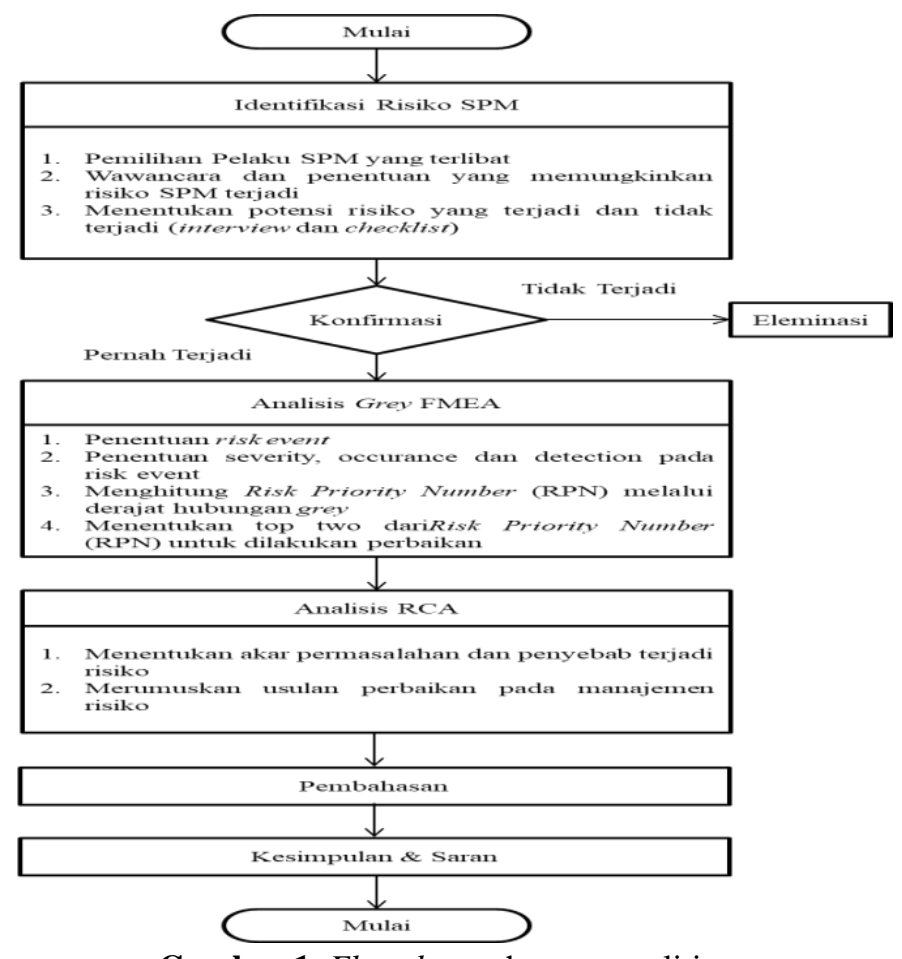

Gambar 1. Flowchart tahapan penelitian Sumber: Tahapan riset (2022) 
Berdasarkan Gambar 1 maka tahapan dapat dijelaskan sebagai berikut:

1. Identifikasi Risiko supply chain management, dimulai dari pemetaan aliran distribusi untuk mengetahui pelaku SPM yang terlibat. Selanjutnya menentukan faktor-faktor risiko yang memungkinkan menghambat aliran distribusi melalui wawancara, interview dan checklist pada pelaku terkait [8].

2. Analisis Risiko supply chain management menggunakan metode Grey FMEA dilakukan dari menentukan nilai risk event dan menganalisa dampak dari suatu risiko berdasarkan severity, occurrence dan detection. Severity, occurrence dan detection ditentukan untuk mengetahui keseriusan dari risiko, frekuansi kejadian risiko, dan kemudahan dalam mendeteksi risiko [9]. Selanjutnya adalah menghitung nilai RPN pada setiap risiko dengan menggunakan pendekatan metode Grey FMEA untuk menentukan 2 risiko prioritas untuk dicari akar permasalah.

3. Analisis Pencarian Akar Permasalahan dimulai dengan penggunaan metode RCA 5 whys tools, yaitu risiko prioritas yang telah ditentukan kemudian dicari akar penyebab dengan menggunakan metode RCA 5 whys. Permasalahan yang telah ditemukan selanjutnya dirumuskan strategi alternatif perbaikan pada risiko prioritas.

\section{Analisis Data Metode Grey FMEA}

Metode Grey FMEA atau sering disebut dengan Grey Relational Analysis adalah suatu metode yang digunakan untuk menyelidiki faktor-faktor yang mempengaruhi sistem serta mendeteksi suatu faktor masalah, biasanya diterapkan pada analisis prediksi, evaluasi kinerja, pengambilan keputusan dan identifikasi FMEA (10). Langkah-langkah pengerjaan metode grey FMEA adalah sebagai berikut [11]:

1) Membangun seri perbandingan yaitu mengisi nilai severity, occurrence, dan detection pada masing-masing tipe kegagalan berikut.

$$
\mathrm{X}=\left[\begin{array}{l}
X_{1} \\
X_{2} \\
X_{n}
\end{array}\right]=\left[\begin{array}{c}
X_{1}(1) X_{1}(2) \ldots . . X_{1}(k) \\
X_{2}(1) X_{2}(2) \ldots . . X_{2}(k) \\
\\
X_{n}(1) X_{n}(2) \ldots . . X_{n}(k)
\end{array}\right]
$$

2) Menetapkan seri standar, yaitu dengan mengurangi risiko yang potensial agar nilai faktor keputusanakan menjadi semakin kecil. Standar yang telah ditetapkan adalah sebagai berikut:

$$
\mathrm{X} 0=\left[\mathrm{X}_{0}(1) \mathrm{X}_{0}(2) \mathrm{X}_{0}(3)\right]
$$

3) Mencari perbedaan antara seri standar dan seri perbandingan, dilakukan dengan mengurangi nilaidari seri perbandian dengan seri standar melalui persamaan berikut :

$$
\mathrm{D}_{0}=\left[\begin{array}{c}
\Delta_{01}(1) \Delta_{01}(2) \Delta_{01}(3) \ldots . . \Delta_{01}(k) \\
\Delta_{02}(1) \Delta_{02}(2) \Delta_{02}(3) \ldots . . \Delta_{02}(k) \\
\\
\Delta_{0 m}(1) \Delta_{0 m}(2) \Delta_{0 m}(3) \ldots . . \Delta_{0 j}(k)
\end{array}\right]
$$

Dimana $\Delta_{0 \mathrm{j}}(\mathrm{k})=\|\mathrm{X} 0(\mathrm{k})-\mathrm{Xj}(\mathrm{k})\|$

4) Menghitung koefisien relasional grey melalui :

1. Menentukan nilai maksimum dan minimum dari persamaan (3). $\Delta_{\min }$ dan $\Delta_{\max }$

2. $\zeta$ berupa identifikasi yang memengaruhi nilai relatif dari sebuah risiko tanpa mengubah prioritasnya. Nilai $\zeta$ yang ditentukan adalah 0,5 . Berikut merupakan persamaan dalam meghitung koefisiensi relasional grey:

$$
\begin{gathered}
\gamma\left(\mathrm{X}_{0}(\mathrm{k}), \mathrm{X}_{\mathrm{i}}(\mathrm{k})\right)=\frac{\Delta \min +\zeta \Delta_{\max }}{\Delta_{0 \mathrm{j}}(\mathrm{k})+\zeta \Delta_{\max }} \\
\gamma_{0 \mathrm{i}}(\mathrm{k})=\frac{\Delta \min +\zeta \Delta_{\max }}{\Delta_{\min }(\mathrm{k})+\zeta \Delta_{\max }} \ldots \ldots \ldots \ldots \ldots
\end{gathered}
$$

$$
\text { Dimana, } \mathrm{j}=1, \ldots \ldots, \mathrm{m} \mathrm{k}=1, \ldots, \mathrm{n}
$$


5) Menentukan derajat hubungan, melalui persamaan berikut:

$$
\begin{aligned}
& \Gamma\left(\mathrm{X} i, \mathrm{X}_{\mathrm{j}}\right)=\frac{1}{n} \sum_{k=1}^{n} \gamma\left(\mathrm{x}_{\mathrm{i}}(k), \mathrm{x}_{\mathrm{j}}(k)\right) \\
& \Gamma_{0 \mathrm{i}}(\mathrm{k})=\frac{1}{3} \sum_{k=1}^{3} \gamma_{0 i}(k)
\end{aligned}
$$

6) Langkah terakhir adalah mengurutkan risiko prioritas berdasarkan tingkat risiko dari nilai derajat hubungan grey terkecil hingga terbesar.

\section{Analisis Metode Data Root Cause Analysis (RCA)}

Root Cause Analysis merupakan salah satu metode yang berfungsi untuk mengidentifkasi dan menganalisis suatu kegagalan suatu sistem serta memperbaiki kegagalan tersebut [12]. Terdapat langkahlangkah RCA yang dapat dilakukan, diantaranya mengidentifikasi risiko kejadian, mencari akar permasalahan pada risiko kejadian melalui pertanyaan "mengapa" dan memberikan solusi perbaikan pada risiko kejadian tersebut [13]. Metode RCA yang akan digunakan disebut dengan sistem 5 whys, yang dilakukan dengan mengulangi pertanyaan yang diawali dengan kata "mengapa" sebanyak 5 kali [14].

\section{Hasil dan Pembahasan}

\section{Identifikasi Risiko Supply Chain Management}

Data identifikasi risiko diperolah dari hasil pengamatan lapangan dan wawancara bersama bagian Jr. Supervisor Receiving \& Storage, maka didapatkan risiko Supply Chain Management yang memperlambat fungsi operasi \& distribusi perusahaan. Berikut merupakan rekapitulasi data risiko pada supply chain management.

Tabel 1. Risiko pada Supply Chain Management

\begin{tabular}{cl}
\hline No. & \multicolumn{1}{c}{ Failure/Risk } \\
\hline 1. & Keterlambatan kapal tanker \\
2. & Kapasitas storage/penyimpanan kurang memadai \\
3. & Sinkronisasi kelancaraan arus informasi antara pelaku Supply Chain \\
4. & Dukunement belum efektif \\
5. & Sistem antrian distribusi yang belum sinkron dengan pemasok produk \\
6. & Standar sistem sarfas storage /penyimpanan masih rendah \\
7. & Proses discharge kapal tanker tidak capable sesuai permintaan bagian darat \\
8. & Pompa penyaluran produk BBM tidak memenuhi standar dan maintenance yang \\
\hline
\end{tabular}

Sumber: Data hasil identifikasi (2022)

\section{Perhitungan Prioritas Risiko}

Perhitungan risiko dimulai dari mencari nilai hubungan grey FMEA terkecil untuk dijadikan prioritas pencarian akar permasalahan. Maka diperlukan penentuan nilai severity, occurrence, dan detection untuk melihat kefatalan, frekuensi kejadian dan kemudahan dideteksi. Data nilai tersebut diperoleh dari konsultasi bersama Jr. Supervisor Receiving \& Storage. Berikut adalah hasil dari rekapitulasi nilai severity, occurrence, dan detection.

Tabel 2. Hasil rekapitulasi nilai severity, occurrence, dan detection

\begin{tabular}{clccc}
\hline No. & \multicolumn{1}{c}{ Failure/Risk } & O & D \\
\hline 1. & Keterlambatan kapal tanker & 7 & 6 & 5 \\
2. & Kapasitas storage/penyimpanan kurang memadai & 3 & 5 & 8 \\
3. & Sinkronisasi kelancaraan arus informasi antara pelaku Supply Chain & 4 & 5 & 3 \\
4. & Management belum efektif & 5 & 6 & 6 \\
5. & Sistem antrian distribusi yang belum sinkron dengan pemasok produk & 2 & 3 & 5 \\
6. & Standar sistem sarfas storage /penyimpanan masih rendah & 7 & 6 & 4 \\
7. & Proses discharge kapal tanker tidak capable sesuai permintaan bagian darat & 4 & 5 & 5 \\
8. & Pompa penyaluran produk BBM tidak memenuhi standar dan maintenance & 2 & 4 & 5 \\
\hline
\end{tabular}

Sumber: Data hasil analisis (2022) 
Setelah penentuan nilai severity, occurrence, dan detection pada risiko, selanjutnya menghitung RPN(Risk Priority Number) dengan menggunakan metode Grey FMEA yang kemudian diranking mulai dari nilai hubungan grey terkecil hingga ke terbesar. Berikut adalah langkah pengerjaannya:

- Membangun seri perbandingan

Langkah ini dilakukan dengan memasukkan hasil nilai pembobotan severity, occurrence, dan detection pada masing-masing risiko yang terjadi. Berikut adalah hasil tampilannya:

- Menetapkan seri standar

$$
\text { Risiko }=\left[\begin{array}{lll}
7 & 6 & 5 \\
3 & 5 & 8 \\
4 & 5 & 3 \\
5 & 6 & 6 \\
2 & 3 & 5 \\
7 & 6 & 4 \\
4 & 5 & 5 \\
2 & 4 & 5
\end{array}\right]
$$

Penetapan seri standar dilakukan dengan menetapkan nilai severity, occurrence, dan detection yang terkecil pada seri perbandingan. Berikut adalah hasil penetapan seri standar:

$$
\mathrm{X}_{\mathrm{P}}=\left[\mathrm{X}_{0}(1) \mathrm{X}_{0}(2) \mathrm{X}_{0}(3)\right]=\left[\begin{array}{ll}
2 & 2
\end{array}\right]
$$

- Mencari perbedaan antara seri standar dan seri perbandingan

Pada tahap ini dilakukan dengan mengurangi nilai dari seri perbandingan seri standar sesuai dengan persamaan (3). Maka didapatkan sebagai berikut:
$\Delta_{01}(\mathrm{~S} 1)=7-2=5$
$\Delta_{01}(\mathrm{O} 1)=6-2=4$
$\Delta_{02}(\mathrm{~S} 2)=3-2=1$
$\Delta_{02}(\mathrm{O} 2)=5-2=3$
$\Delta_{03}(\mathrm{~S} 3)=4-2=2$
$\Delta_{03}(\mathrm{O} 3)=5-2=3$
$\Delta_{04}(\mathrm{O} 4)=6-2=4$
$\Delta_{04}(\mathrm{~S} 4)=5-2=3$
$\Delta_{05}(\mathrm{O} 5)=3-2=1$
$\Delta_{05}(\mathrm{~S} 5)=2-2=0$
$\Delta_{06}(\mathrm{O} 6)=6-2=4$
$\Delta_{07}(\mathrm{O} 7)=5-2=3$
$\Delta_{07}(\mathrm{~S} 7)=4-2=2$
$\Delta_{08}(\mathrm{O} 8)=4-2=2$
$\Delta_{01}(\mathrm{D} 1)=5-2=3$
$\Delta_{02}(\mathrm{D} 2)=8-2=6$
$\Delta_{03}(\mathrm{D} 3)=3-2=1$
$\Delta_{04}(\mathrm{D} 4)=6-2=4$
$\Delta_{05}(\mathrm{D} 5)=5-2=3$
$\Delta_{06}(\mathrm{D} 6)=4-2=2$
$\Delta_{07}(\mathrm{D} 7)=5-2=3$
$\Delta_{08}(\mathrm{D} 8)=5-2=3$

- Menghitung koefisien relasional Grey dan derajat hubungan Grey

Koefisien relasional grey diperoleh berdasarkan persamaan (4), dimana terlebih dahulu menentukan nilai minimum dan maksimum dari langkah ketiga diatas, sehingga diperoleh:

$\Delta_{0 \mathrm{i}} \min =0$

$\Delta_{0 \mathrm{i}} \max =6$

Maka hasil rekapitulasi nilai koefisien relasional grey didapatkan:

$\begin{array}{lll}\gamma_{01}(\mathrm{~S} 1)=0,38 & \gamma_{01}(\mathrm{O} 1)=0,43 & \gamma_{01}(\mathrm{D} 1)=0,50 \\ \gamma_{02}(\mathrm{~S} 2)=0,75 & \gamma_{02}(\mathrm{O} 2)=0,50 & \gamma_{02}(\mathrm{D} 2)=0,33 \\ \gamma_{03}(\mathrm{~S} 3)=0,60 & \gamma_{03}(\mathrm{O} 3)=0,50 & \gamma_{03}(\mathrm{D} 3)=0,75 \\ \gamma_{04}(\mathrm{~S} 4)=0,50 & \gamma_{04}(\mathrm{O} 4)=0,53 & \gamma_{04}(\mathrm{D} 4)=0,43 \\ \gamma_{05}(\mathrm{~S} 5)=1,00 & \gamma_{05}(\mathrm{O} 5)=0,75 & \gamma_{05}(\mathrm{D} 5)=0,50 \\ \gamma_{06}(\mathrm{~S} 6)=0,38 & \gamma_{06}(\mathrm{O} 6)=0,43 & \gamma_{06}(\mathrm{D} 6)=0,60 \\ \gamma_{07}(\mathrm{~S} 7)=0,60 & \gamma_{07}(\mathrm{O} 7)=0,50 & \gamma_{07}(\mathrm{D} 7)=0,50 \\ \gamma_{08}(\mathrm{~S} 8)=1,00 & \gamma_{08}(\mathrm{O} 8)=0,60 & \gamma_{08}(\mathrm{D} 8)=0,50\end{array}$

- Menghitung Derajat Hubungan Grey

Adapun langkah selanjutnya yaitu menghitung hasil derajat hubungan grey berdasarkan persamaan (5), yang didapatkan hasil sebagai berikut:
$\Gamma_{01}=0,435$
$\Gamma_{04}=0,452$
$\Gamma_{07}=0,533$
$\Gamma_{02}=0,528$
$\Gamma_{05}=0,750$
$\Gamma_{08}=0,700$
$\Gamma_{03}=0,617$
$\Gamma_{06}=0,468$ 
Setelah menghitung derajat hubungan grey, langkah terakhir adalah mengurutkan derajat hubungan tersebut dari terkecil hingga yang terbesar. Berikut merupakan hasil rangking dari derajat hubungan grey yang ditunjukkan pada Tabel 3.

Tabel 3. Hasil rangking derajat hubungan grey

\begin{tabular}{clc}
\hline No. & \multicolumn{1}{c}{ Failure/Risk } & $\Gamma_{\mathrm{oj}}$ \\
\hline 1. & Keterlambatan kapal tanker & 0,435 \\
2. & Kapasitas storage/penyimpanan kurang memadai & 0,528 \\
3. & Sinkronisasi kelancaraan arus informasi antara pelaku Supply Chain & 0,617 \\
4. & Management belum efektif & 0,452 \\
5. & Sistem antrian distribusi yang belum sinkron dengan pemasok produk & 0,750 \\
6. & Standar sistem sarfas storage /penyimpanan masih rendah & 0,468 \\
7. & Proses discharge kapal tanker tidak capable sesuai permintaan bagian darat & 0,533 \\
8. & Pompa penyaluran produk BBM tidak memenuhi standar dan maintenance yang & 0,700 \\
\hline
\end{tabular}

Sumber : Hasil pengolahan metode Grey FMEA (2022)

Berdasarkan Tabel 3, dapat dilihat bahwa 2 risiko yang memiliki hubungan grey terkecil yaitu keterlambatan kapal tanker dan Dukungan interkoneksi sistem informasi antar fungsi masih bermasalah. Risiko tersebut harus diprioritaskan untuk dicari akar permasalahannya agar dapat dilakukan perbaikan.

Analisis Akar Masalah dengan Metode Root Cause Analysis

Setelah menentukan prioritas risiko supply chain management yang memiliki hubungan grey terkecil, maka selanjutnya dilakukan pencarian akar permasalahan dengan menggunakan root cause analysis jenis 5 whys. Adapun pencarian akar permasalahan supply chain management adalah sebagai berikut:

\section{Keterlambatan Kapal Tanker}

Keterlambatan kapal tanker merupakan salah satu risiko yang paling memberi pengaruh terhadap risiko supply chain management. Berikut adalah analisis RCA 5 whys pada risiko keterlambatan kapal tanker:

Tabel 4. Analisis RCA 5 Whys keterlambatan kapal tanker

\begin{tabular}{|c|c|c|c|c|c|}
\hline Failure & Why 1 & Why 2 & Why 3 & Why 4 & Why 5 \\
\hline \multirow{3}{*}{$\begin{array}{l}\text { Keterlambatan } \\
\text { kapal tanker }\end{array}$} & $\begin{array}{l}\text { Kesalahan } \\
\text { teknis pada } \\
\text { mesin kapal }\end{array}$ & $\begin{array}{l}\text { Pelaksanaan } \\
\text { tidak sesuai } \\
\text { dengan SOP }\end{array}$ & $\begin{array}{l}\text { Peralatan } \\
\text { kurang } \\
\text { memadai }\end{array}$ & $\begin{array}{l}\text { Sarana dan } \\
\text { prasarana } \\
\text { terbatas }\end{array}$ & $\begin{array}{l}\text { Tidak rutinnya } \\
\text { maintenance } \\
\text { /perawatan } \\
\text { pada mesin } \\
\text { kapal }\end{array}$ \\
\hline & $\begin{array}{l}\text { Awak kapal } \\
\text { kurang lihai } \\
\text { dalam } \\
\text { melajukan } \\
\text { kapal }\end{array}$ & $\begin{array}{l}\text { Kurangnya skill } \\
\text { pada awak kapal } \\
\text { Pekerja lamban } \\
\text { dalam } \\
\text { melaksanakan } \\
\text { fungsi }\end{array}$ & $\begin{array}{l}\text { Kurangnya } \\
\text { pengalaman } \\
\text { pada awak } \\
\text { kapal }\end{array}$ & $\begin{array}{l}\text { Kurangnya } \\
\text { pelatihan pada } \\
\text { awak kapal } \\
\text { sesuai fungsi }\end{array}$ & \\
\hline & $\begin{array}{l}\text { Kondisi cuaca } \\
\text { buruk }\end{array}$ & & & & \\
\hline
\end{tabular}

Sumber : Hasil pencarian akar permasalahan (2022)

Hasil analisis RCA 5 whys pada risiko keterlambatan kapal tanker diketahui bahwa, terdapat 2 kondisi akar permasalah yang terjadi yaitu permasalahan dapat dikendalikan dan permasalahan tidak dapat dikendalikan. Kondisi akar permasalahan yang tidak dapat dikendali berupa faktor cuaca, karena sesuatu yang tidak dapat dikendalikan oleh manusia. Selain itu akar permasalahan yang dapat dikendalikan adalah kurangnya pelatihan pada pekerja sehingga kelihaian pekerja dalam melajukan kapal kurang efisien serta terbatasnya sarana dan prasarana membuat pekerja mengabaikan rutinitas pelaksanaan maintancel perawatan sesuai SOP.

Berdasarkan akar permasalahan, perbaikan yang bisa dilakukan oleh pihak perusahaan pada akar permasalahan kondisi cuaca buruk yang berupa angin kencang dan curah hujan yang tinggi adalah menjalin kerja sama dengan pihak BMKG. Tujuan menjalin kerjasama dengan pihak BMKG adalah untuk membantu memperkirakan dan memonitoring perubahan cuaca [15]. Sedangkan akar permasalahan kurangnya 
pelatihan pada awak kapal, dapat diatasi dengan membuat pelatihan-pelatihan khusus kepada pekerja sesuai dengan fungsi pekerjaannya sehingga dapat meningkatnya sumber daya manusia yang berkualitas. Selanjutnya akar permasalahan tidak rutinnya maintance/perawatan, alternatif strategi yang dapat diberikan adalah dengan menyediakan sarana dan prasarasana peralatan yang memadai dan teknisi yang handal.

\section{Dukungan Interkoneksi Sistem Informasi Antar fungsi Masih Bermasalah}

Hasil grey FMEA menunjukkan dukungan risiko sistem informasi pada perusahaan menempati risiko kedua terendah, dimana termasuk risiko yang harus diprioritaskan untuk ditangani kedepannya dan diperlukan analisis akar sebab permasalahan. Adapun analisis RCA 5 why adalah sebagai berikut:

Tabel 5. Analisis RCA 5 Whys dukungan interkoneksi sistem informasiantar fungsi masih bermasalah

\begin{tabular}{cccccc}
\hline Failure & Why 1 & Why 2 & Why 3 & Why 4 & Why 5 \\
\hline Dukungan & Penggunaan & Koneksi/jaringan & Perangkat & Terbatasnya & Kurangnnya \\
interkoneksi & sistem & yang digunakan & koneksi/jaringan & sarana dan & Melaksanakan \\
sistem informasi & infromasi & sistem informasi & tidak berfungsi & Prasaran & Perawatan \\
antar pelaku & sering & lamban & dengan baik & perawatan & Perangkat \\
masih bermasalah & mengalami & & & perangkat & koneksi/jaringan \\
& error & & & & \\
\hline
\end{tabular}

Sumber : Hasil pencarian akar permasalahan (2022)

Berdasarkan hasil analisis risiko 5 whys, didapatkan akar permasalahan pada dukungan sistem informasi antar fungsi diperusahaan adalah kurangnnya melaksanakan perawatan pada perangkat koneksi/jaringan. Kurangnya perawatan pada perangkat koneksi/jaringan ini menyebabkan perangkat seperti kabel LAN, konektor, switch, wifi dan perangkat lainnya tidak berfungsi dengan baik. Hal ini dikarenakan sarana dan prasarana yang terbatas sehingga tidak rutinnya perawatan. Alternatif perbaikan yang dapat dilakukan adalah perusahaan harus bekerja sama dengan perusahaan jasa manage service. Manage service adalah sebuah layanan jasa yang dapat mendukung perusahaan lainnya dalam hal mengelola, memonitoring dan perawatan pada sistem informasi serta sistem koneksi perusahaan.

\section{Kesimpulan}

Risiko yang menjadi kendala utama berdasarkan derajat hubungan grey adalah keterlambatan kapal tanker dengan nilai 0,435 dan dukungan interkoneksi sistem informasi antar fungsi masih bermasalah dengan nilai 0,452 . Analisis akar permasalahan yang dilakukan pada risiko kendala utama keterlamabatan kapal yaitukondisi cuaca buruk yang berupa angin kencang dan curah hujan yang tinggi. Mitigasi yang dapatdilakukan perusahaan adalah bekerja sama dengan pihak BMKG untuk membantu memprediksikan cuaca. Selain itu akar permasalahan lainnya adalah kurangnya maintance pada mesin kapaldikarena sarana dan prasarana yang kurang memadai. Alternatif strategi perbaikan yang dapat diberikan adalah mengusulkan menyediakan peralatan yang memadai dan mekanik yang handal dalam menangani sarana dan prasana yang dibutuhkan kapal tanker.

Akar permasalahan yang terjadi adalah kondisi cuaca buruk sehingga mempengaruhi jaringan sistem informasi disetiap fungsi. Perbaikan yang bisa dilakukan perusahaan adalah menyediakan perangkat yang lebih mumpuni dan tahan kondisi cuaca buruk seperti perangkat antena, kabel jaringan, dan konektor. Akar permasalahan selanjutnya adalah kurangnnya maintanance pada perangkat seperti kabel LAN, kabel jaringan, dan konektor dikarenakan kurangnya sarana dan prasarana. Adapun usulan perbaikan yang dapat dilakukan adalah perusahaan harus menjalin kerja sama bersama perusahaan jasa manage service.

\section{Ucapan Terima Kasih}

Penulis mengucapkan terima kasih kepada rekan-rekan Universitas Teuku Umar dan PT Pertamina Fuel Terminal Meulaboh yang telah memberikan wawasan dan keahlian untuk membantu menyelesaikan penelitian ini.

\section{Singkatan}

$$
\begin{array}{ll}
\text { SPM } & =\text { Supply Chains Management } \\
\text { BBM } & =\text { Bahan Bakar Minyak } \\
\text { CBM } & =\text { Conventional Bouy Mooring } \\
\text { FT } & =\text { Fuel Terminal } \\
\text { FMEA } & =\text { Failure Mode and Effect Analysis } \\
\text { RCA } & =\text { Root Cause Analysis }
\end{array}
$$




$$
\begin{array}{ll}
\hline \text { LAN } & =\text { Local Area Network } \\
\text { BMKG } & =\text { Badan Meteorologi, Klimatologi, dan Geofisika } \\
\text { SOP } & =\text { Standard Operating Procedure }
\end{array}
$$

\section{Referensi}

[1] A. H. K. Nadhira, T. Oktiarso dan T. D. Harsoyo, "Manajemen risiko rantai pasok produk sayuran menggunakan metode supply chain operation reference dan model house of risk," Kurawal-Jurnal Teknologi, Informasi dan Industri, Vol. 2, No. 2, Hal. 101-117, 2019.

[2] I. D. Utami, "Pendekatan Socio Technical Framework Guna Mereduksi Risiko Pada Supply Chain,"pada Seminar Nasional Teknik Industri Waluyo Jatmiko, 2017.

[3] Faizah, Arlinda Dewi Nur dan Much Djunaidi, "Analisis Risiko Pada Halal Supply Chain Bakso Dengan House of Risk Di UD Nur Cahaya," Skripsi thesis, Universitas Muhammadiyah Surakarta, 2020.

[4] S. Suharjito, M. Marimin, M. Machfud, B. Haryanto, dan S. Sukardi, "Identifikasi dan evaluasi risiko manajemen rantai pasok komoditas jagung dengan pendekatan logika fuzzy," J. Manajemen dan Organisasi, Vol. 1, No. 2, Hal. 118-134, 2010.

[5] Wilbert, T. S., \& Rambe, A. J. M. Penerapan preventive maintenance dengan menggunakan metode realibility centered maintenace dengan mengaplikasikan grey fmea pada pt. Wxy. e-Jurnal Teknik Industri, FT USU, Vol. 1, No. 3, Hal. 53-59, 2013.

[6] R. Kusumastuti, P. A. Setiawan dan A. Subekti, "Perencanaan kegiatan preventive maintenance pada pompa menggunakan metode $\mathrm{rcm}$ ii (reliability centered maintenance) dengan mengaplikasikan grey fmea di perusahaan minyak dan gas bumi," pada Seminar K3, Vol. 1, No. 1, pp. 334-340, 2017.

[7] R. A. Albanna, "Mereduksi pemborosan pada jasa pengiriman barang pt qwz dengan aplikasi lean service," Masters Thesis, Institut Teknologi Sepuluh Nopember, 2018.

[8] N. Badariah, D. Surjasa, dan Y. Trinugraha, "Analisa supply chain risk management berdasarkan metode failure mode and effects analysis (fmea)," J. Teknik Industri, Vol. 2, No. 2, Hal. 110-118, 2012.

[9] R. A. Astari dan A. K. Al Ghofari, "Pengelolaan risiko supply chain management pertamax dengan grey failure mode and effect analysis dan fault tree analysis pt. pertamina balongan," Skripsi Thesis, Universitas Muhammadiyah Surakarta, 2021.

[10] C. Ünlükal, M. Şenel and B. Şenel, "Risk assessment with failure mode and effects analysis and grey relational analysis method in plastic injection process," in ITM Web of Conferences, Vol. 22, No. 4, p. 01023, EDP Sciences, 2018.

[11] H. J. S. Naibaho, "Pengendalian kualitas crude palm oil (cpo) dengan menggunakan metode define, measure, analyze, improve, control (dmaic) dan grey failure mode and effect analysis (fmea)," Skripsi, Universitas Sumatera Utara, 2018.

[12] F. Yanto, "Identifikasi keterlambatan pengiriman produk di pt x pada departemen material preparation control," J. Titra, Vol. 6, No. 2, Hal. 65-72, 2018.

[13] V. D. Puspitasari, "Minimasi waste pada proses produksi sari apel dengan menggunakan metode leansix sigma (studi kasus pt. batu bhumi suryatama)," Skripsi, University of Muhammadiyah Malang, 2019.

[14] V. E. Ateng, R. Rahmahwati dan Y. E. Prawatya, "Usulan perbaikan sistem k3 menggunakan metode fmea dan rca pada pt. xyz," J. TIN Universitas Tanjungpura, Vol. 5, No. 1, 2021.

[15] D. Endraswara, M. Basuki dan A. I. Kusuma, "Penilaian risiko proses bongkar curah kering menggunakan metode fmea (failure mode and effect Analysis) di PT. XYZ," pada Seminar Nasional Sains dan Teknologi Terapan V, Institut Teknologi Adhitama, Surabaya, 2017. 